\title{
Intradiskal Injection of Methylene Blue for Discogenic Back Pain: A Meta-Analysis of Randomized Controlled Trials
}

\author{
Ming Deng ${ }^{1, \#}$ Hui Huang, ${ }^{2, \#}$ Yong-gang Ma ${ }^{1}$ Yan Zhou ${ }^{1}$ Qing Chen ${ }^{1}$ Ping Xie $^{3}$
}

${ }^{1}$ Department of Orthopedics, Renmin Hospital of Wuhan University, Wuhan, Hubei Province, P. R. China

2 Department of Orthopedics, Hainan Provincial People's Hospital, Haikou, Hainan, P. R. China

${ }^{3}$ Department of Chinese Traditional Medicine, Tongren Hospital of

Address for correspondence Ping Xie, MD, Department of Chinese Traditional Medicine, Tongren Hospital of Wuhan University, No. 241, Peng Liu Yang Road, Wuchang District, Wuhan, Hubei Province, P. R. China (e-mail: 395460475@qq.com).

Wuhan University, Wuhan, Hubei Province, P. R. China

J Neurol Surg A 2021;82:161-165.

Abstract
Keywords
- methylene blue
- intradiskal injection
- discogenic back pain
- randomized
controlled trials
- meta-analysis

Introduction Intradiskal injection of methylene blue has some potential in alleviating discogenic back pain. This meta-analysis aims to explore the impact of intradiskal injection of methylene blue for discogenic back pain.

Methods Several databases such as PubMed, EMbase, Web of Science, EBSCO, and Cochrane Library databases have been searched through November 2019, and randomized controlled trials (RCTs) assessing the effect of intradiskal injection of methylene blue for discogenic back pain are included.

Results Three RCTs are included in the meta-analysis. Overall, compared with control group for discogenic back pain, intradiskal injection of methylene blue remarkably decreased pain scores at 3 months (mean difference $[\mathrm{MD}]=-0.71 ; 95 \%$ confidence interval $[\mathrm{Cl}]=-0.96$ to $-0.46 ; p<0.00001)$ and 6 months $(\mathrm{MD}=-13.92 ; 95 \%$ $\mathrm{Cl}=-22.31$ to $-5.54 ; p=001)$ and Oswestry Disability Index (ODI) at 4 to 6 weeks $(\mathrm{MD}=-10.39 ; 95 \% \mathrm{Cl}=-16.95$ to $-3.83 ; p=0.002)$ and 3 months $(\mathrm{MD}=-3.66 ; 95 \%$ $\mathrm{Cl}=-4.85$ to $-2.48 ; p<0.00001)$, but demonstrated no obvious effect on ODI at 6 months ( $\mathrm{MD}=-11.76 ; 95 \% \mathrm{Cl}=-33.33$ to $9.80 ; p=0.28$ ).

Conclusions Intradiskal injection of methylene blue can substantially decrease pain scores and improve function for discogenic back pain.

\section{Introduction}

Discogenic back pain is one of the most common types of low back pain, accounting for 28 to $43 \%$ of the patients with low back pain. ${ }^{1-3}$ Discogenic back pain is mainly caused by internal disk disruption and vascularized granulation tissue containing nociceptive nerves. ${ }^{4-6}$ Reduction of inflammation and/or ablation of the nociceptive nerves in the outer

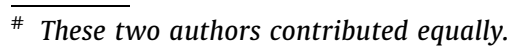

annulus are beneficial to alleviate discogenic back pain., Current treatment methods include anti-inflammation strategy and invasive procedures. ${ }^{9}$

Methylene blue is a low-molecular weight, partially liposoluble vital dye. ${ }^{10,11}$ It is widely used for destruction of free nociceptive nerve endings for the relief of pain, inhibition of nitric oxide synthesis, and neuroprotective effect. ${ }^{10,12-15}$ Its promotion to pain control is derived from inhibition of free radical generation, deactivation of xanthine oxidase, and inhibition of the production of nitric oxide. ${ }^{16}$

(c) 2021. Thieme. All rights reserved. Georg Thieme Verlag KG, Rüdigerstraße 14, 70469 Stuttgart, Germany
DOI https://doi.org/ 10.1055/s-0040-1721015. ISSN 2193-6315. 

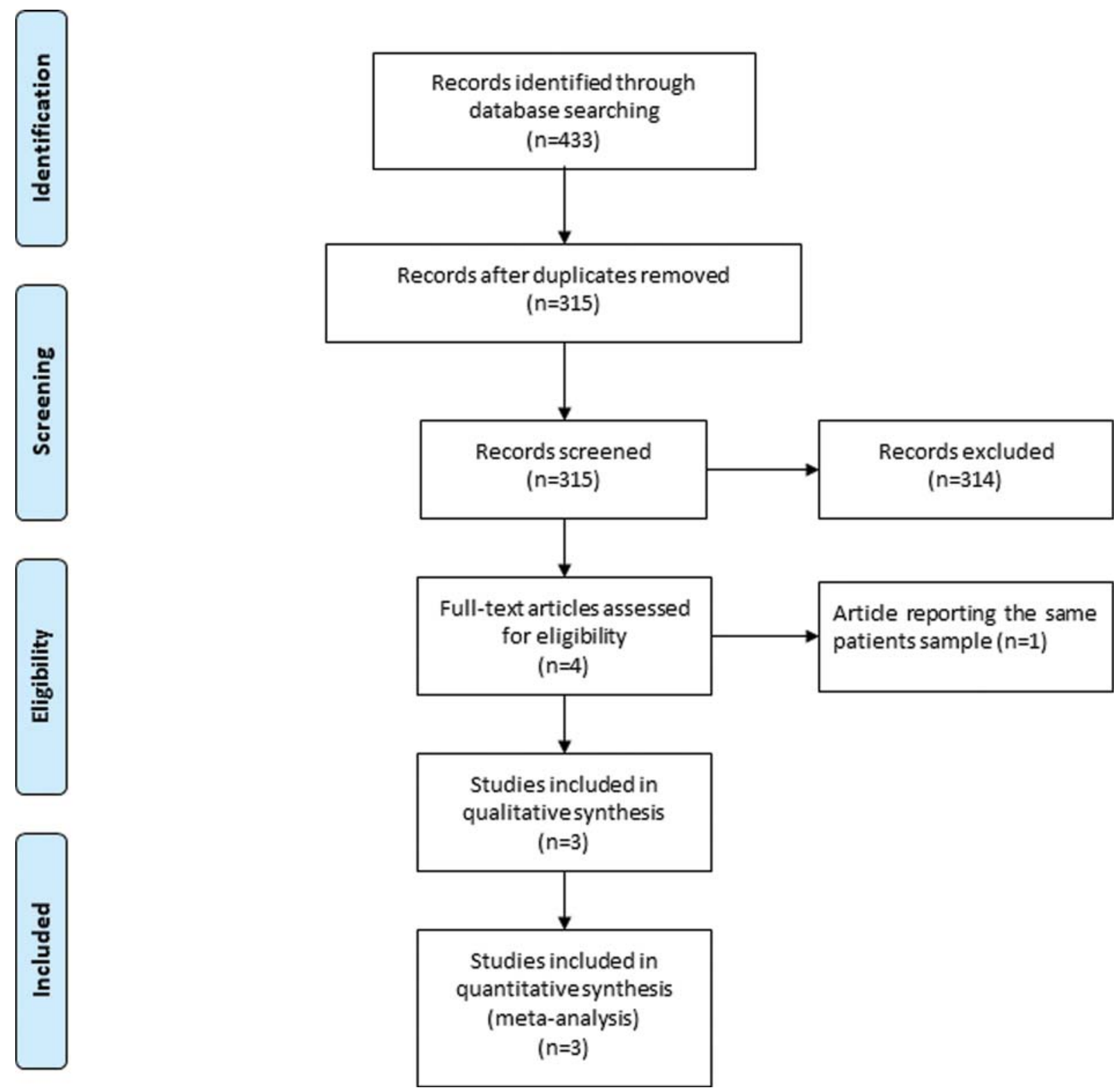

Fig. 1 Flow diagram of study searching and selection process.

Several studies have documented the potential of intradiskal injection of methylene blue for discogenic back pain, but there were some conflicting results. ${ }^{17-19}$ This metaanalysis aims to investigate intradiskal injection of methylene blue for pain control in patients with discogenic back pain.

\section{Materials and Methods}

This was a systematic review and meta-analysis of previously published studies, and no ethical approval and patient consent were required. This meta-analysis was performed based on Preferred Reporting Items for Systematic Reviews and Meta-Analyses (PRISMA). ${ }^{20}$

\section{Search Strategy and Study Selection}

Two investigators searched the following databases (inception to November 2019): PubMed, EMbase, Web of Science,
EBSCO, and Cochrane Library databases. The keywords for electronic search strategy were discogenic back pain, and methylene blue. The inclusive selection criteria were as follows: (1) study design was randomized controlled trial (RCT); (2) patients were diagnosed with discogenic back pain; (3) intervention treatments were intradiskal injection of methylene blue versus placebo (or ozone ablation).

\section{Data Extraction and Outcome Measures}

We have extracted the following information: author, number of patients, age, male, pain duration, and detail methods in each group, etc. Data have been extracted independently by two investigators, and discrepancies are resolved by consensus. We also contacted the corresponding author to obtain the data when necessary.

The primary outcomes are pain scores at 3 and 6 months. Secondary outcomes include Oswestry Disability Index (ODI) at 4 to 6 weeks, 3 months, and 6 months. 
Table 1 Characteristics of included studies

\begin{tabular}{|c|c|c|c|c|c|c|c|c|c|c|c|c|}
\hline \multirow[t]{2}{*}{ No. } & \multirow[t]{2}{*}{ Author } & \multicolumn{5}{|c|}{ Methylene blue group } & \multicolumn{5}{|c|}{ Control group } & \multirow{2}{*}{$\begin{array}{l}\text { Jada } \\
\text { scores }\end{array}$} \\
\hline & & No. & $\begin{array}{l}\text { Age } \\
\text { (y) }\end{array}$ & $\begin{array}{l}\text { Male } \\
(n)\end{array}$ & $\begin{array}{l}\text { Pain } \\
\text { duration } \\
\text { (y) }\end{array}$ & Methods & No. & $\begin{array}{l}\text { Age } \\
\text { (y) }\end{array}$ & $\begin{array}{l}\text { Male } \\
(n)\end{array}$ & $\begin{array}{l}\text { Pain } \\
\text { duration } \\
\text { (y) }\end{array}$ & Methods & \\
\hline 1 & $\begin{array}{l}\text { Kallewaard } \\
\text { et al } 2019\end{array}$ & 40 & $\begin{array}{l}41.2 \\
(9.6)\end{array}$ & 11 & $\begin{array}{l}10.2 \\
(8.8)\end{array}$ & $\begin{array}{l}\text { a mixture of } 1-\mathrm{mL} \\
\text { methylene blue (10 } \\
\mathrm{mg} / \mathrm{mL}), 0.5-\mathrm{mL} \text { lido- } \\
\text { caine hydrochloride } \\
2 \%, \text { and } 0.5-\mathrm{mL} \text { con- } \\
\text { trast dye was injected } \\
\text { into the disk }\end{array}$ & 41 & $\begin{array}{l}42.6 \\
(10.2)\end{array}$ & 12 & $\begin{array}{l}8.5 \\
(7.1)\end{array}$ & placebo & 5 \\
\hline 2 & Zhang 2018 & 55 & $\begin{array}{l}38.45 \\
(4.96)\end{array}$ & 34 & $\begin{array}{l}3.91 \\
(1.45)\end{array}$ & $\begin{array}{l}1 \mathrm{ml} \text { of methylene } \\
\text { blue solution at a } \\
\text { concentration of } 1 \% \\
\text { for disk injection }\end{array}$ & 55 & $\begin{array}{l}38.52 \\
(4.93)\end{array}$ & 33 & $\begin{array}{l}3.95 \\
(1.46)\end{array}$ & $\begin{array}{l}\text { ozone } \\
\text { ablation }\end{array}$ & 4 \\
\hline 3 & $\begin{array}{l}\text { Peng et al } \\
2010\end{array}$ & 36 & $\begin{array}{l}42.06 \\
(13.74)\end{array}$ & 21 & $\begin{array}{l}3.5 \\
(1.6)\end{array}$ & $\begin{array}{l}1 \mathrm{ml} \text { of } 1 \% \text { methylene } \\
\text { blue }(10 \mathrm{mg}) \text { was } \\
\text { injected into the dis- } \\
\text { cogram-proven dis- } \\
\text { eased disk }\end{array}$ & 36 & $\begin{array}{l}41.28 \\
(12.84)\end{array}$ & 20 & $\begin{array}{l}3.2 \\
(1.7)\end{array}$ & placebo & 4 \\
\hline
\end{tabular}

\section{Quality Assessment in Individual Studies}

Modified Jadad scale was used to assess the methodological quality of the included studies. ${ }^{21,22}$ There were three items for Jadad scale: randomization ( $0-2$ points), blinding (0-2 points), and dropouts and withdrawals ( $0-1$ points). The score of Jadad scale varied from 0 to 5 points. Jadad score $\geq 3$ indicated high quality, while Jadad score $\leq 2$ suggested low quality. $^{23}$

\section{Statistical Analysis}

We estimate the standard mean difference (MD) with 95\% confidence interval $(\mathrm{CI})$ for all continuous outcomes. The random-effects model is used regardless of heterogeneity. Heterogeneity was reported using the $I^{2}$ statistic, and $I^{2}>50 \%$ indicated significant heterogeneity. ${ }^{24}$ We searched for potential sources of heterogeneity via omitting one study in turn when encountering significant heterogeneity. Publication bias was not evaluated because of the limited number $(<10)$ of included studies. All statistical analyses were performed using Review Manager Version 5.3 (the Cochrane Collaboration, Software Update, Oxford, UK).

\section{Results}

\section{Literature Search, Study Characteristics, and Quality Assessment}

-Fig. 1 demonstrates the flowchart of the search and selection result. Four hundred and thirty-three potentially relevant articles were identified initially, and three RCTs were finally included in the meta-analysis. ${ }^{17-19}$

The baseline characteristics of the three eligible RCTs in the meta-analysis are summarized in - Table 1. The three studies were published between 2010 and 2019, and the total sample size was 263 . Two RCTs compared methylene blue with placebo, ${ }^{17,19}$ and the remaining RCT compared methylene blue with ozone ablation. ${ }^{18}$ One RCT was published in Chinese.
Among the three studies included here, two studies reported pain scores at 3 months, ${ }^{17,18}$ three studies reported pain scores at 6 months, ${ }^{17-19}$ two studies reported ODI at 4 to 6 weeks and at 3 months, ${ }^{17,19}$ and three studies reported ODI at 6 months. ${ }^{17-19}$ Jadad scores of the three included studies varied from 4 to 5 , and all three studies had high quality.

\section{Primary Outcomes: Pain Scores at 3 and 6 Months}

The random-effects model was used, and compared with the control group for discogenic back pain, methylene blue injection substantially decreased pain scores at 3 months (MD =-$0.71 ; 95 \% \mathrm{CI}=-0.96$ to $-0.46 ; p<0.00001)$, with no heterogeneity among the studies $\left(I^{2}=0 \%\right.$, heterogeneity $p=0.62$; - Fig. 2), and 6 months ( $\mathrm{MD}=-13.92 ; 95 \% \mathrm{CI}=--$ 22.31 to $-5.54 ; p=001)$ with significant heterogeneity among the studies ( $I^{2}=100 \%$, heterogeneity $p<0.00001$; - Fig. 3 ).

\section{Sensitivity Analysis}

Significant heterogeneity was observed for pain scores at 6 months. After excluding the study conducted by Peng, ${ }^{18}$ no heterogeneity remained $\left(I^{2}=0 \%\right.$, heterogeneity $\left.p=0.94\right)$. Methylene blue injection still resulted in the decrease in pain scores at 6 months compared with the control group.

\section{Secondary Outcomes}

Methylene blue injection significantly reduced ODI at 4 to 6 weeks ( $\mathrm{MD}=-10.39 ; 95 \% \mathrm{CI}=-16.95$ to $-3.83 ; p=0.002$; -Fig. 4) and ODI at 3 months (MD $=-3.66 ; 95 \% \mathrm{CI}=-4.85$ to $-2.48 ; p<0.00001$; - Fig. 5) compared with control intervention for discogenic back pain, but not ODI at 6 months (MD =11.76; $95 \% \mathrm{CI}=-33.33$ to $9.80 ; p=0.28$; - Fig. 6 ).

\section{Discussion}

Methylene blue is a potent reversible inhibitor of monoamine oxidase $\mathrm{A}$, and has some association with 5- 
164 Methylene Blue for Back Pain Deng et al.

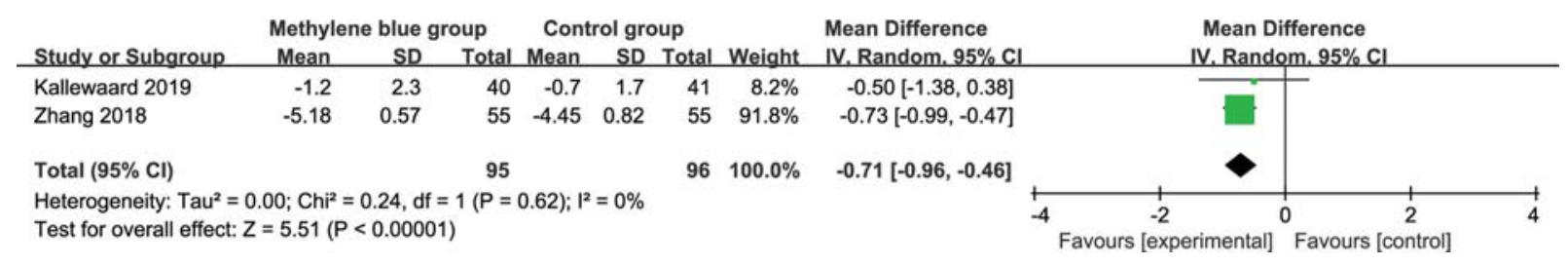

Fig. 2 Forest plot for the meta-analysis of pain scores at 3 months.

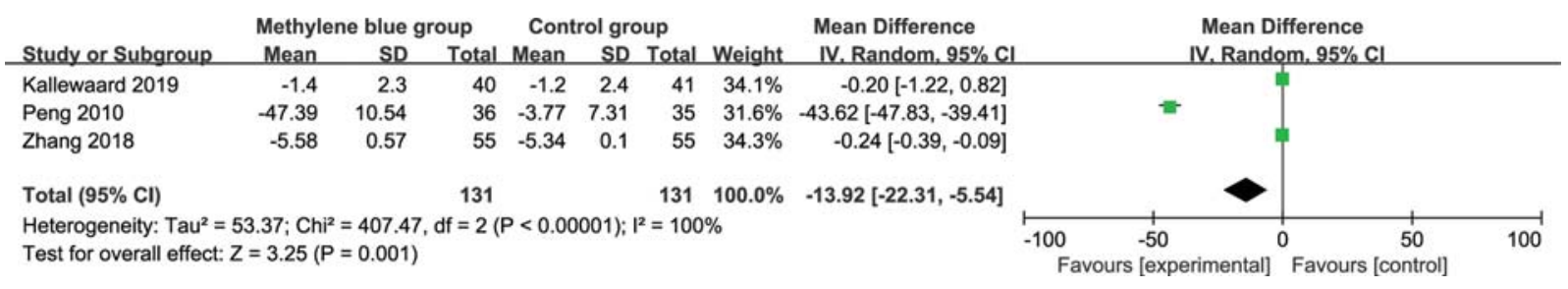

Fig. 3 Forest plot for the meta-analysis of pain scores at 6 months.

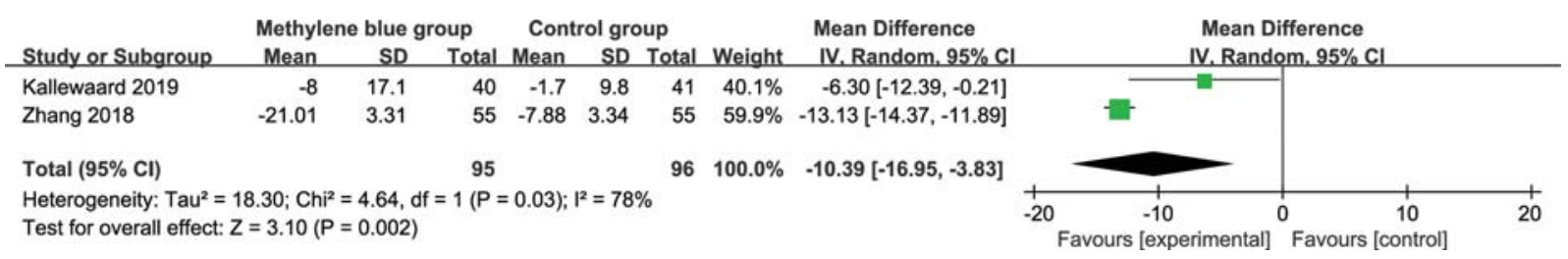

Fig. 4 Forest plot for the meta-analysis of Oswestry Disability Index (ODI) at 4 to 6 weeks.

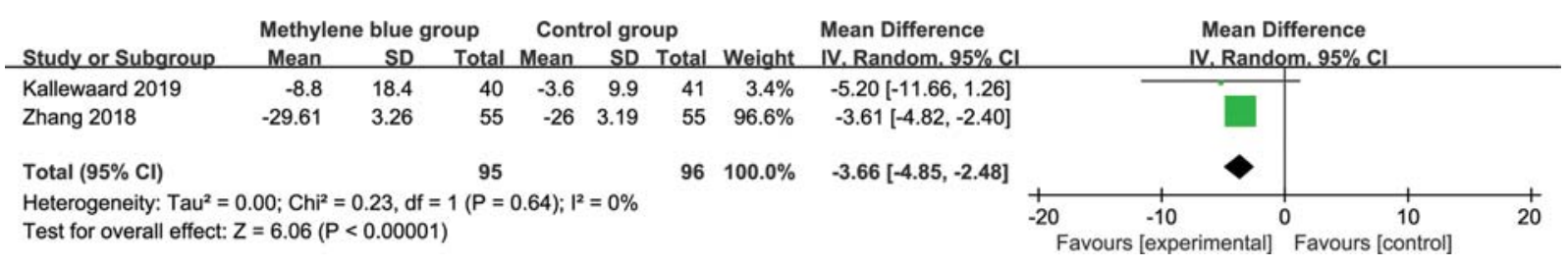

Fig. 5 Forest plot for the meta-analysis of Oswestry Disability Index (ODI) at 3 months.

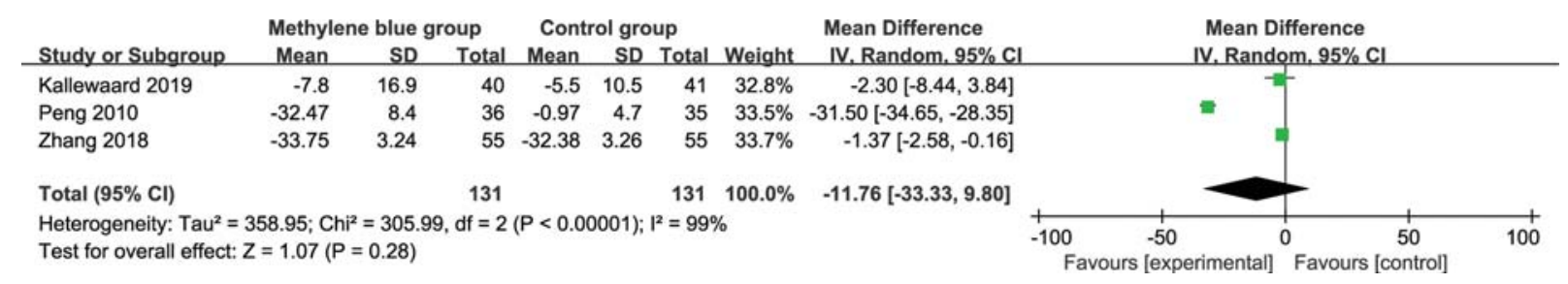

Fig. 6 Forest plot for the meta-analysis of Oswestry Disability Index (ODI) at 6 months.

hydroxytryptamine (5-HT or serotonin) levels. ${ }^{25}$ Serotonin (5-HT) may produce some analgesic effects and modulation in the central nervous system depending on the site of action and the receptor subtype. ${ }^{26,27}$ Methylene blue shows the neurolytic effect and benefits to various painful conditions and idiopathic pruritus ani. ${ }^{28}$ In patients with open lumbar diskectomy, the anti-inflammatory method proved to reduce the low back pain after the surgery. ${ }^{29}$

With the anti-inflammatory effect, methylene blue was reported to significantly decrease low back pain and radicular pain, as well as improve functional outcomes. $^{19,30}$ The follow-up of 2 to 3 months is important to evaluate the safety and efficacy of methylene blue for postoperative pain, and 6 months may be sufficient to assess the pain. Intradiskal methylene blue injection was found to relief at least $30 \%$ of pain in $40 \%$ of the patients with discogenic low back pain at 6 months. ${ }^{31}$ However, another trial revealed no significant pain relief at 6 months after intradiskal methylene blue injection for discogenic low back pain. ${ }^{32}$ 
This meta-analysis concludes that intradiskal methylene blue injection is associated with substantially reduced pain scores at 3 and 6 months, ODI at 4 to 6 weeks and 3 months compared to control intervention in patients with discogenic low back pain, but there is no statistical difference of ODI at 6 months. There is significant heterogeneity for pain scores at 6 months, and this heterogeneity may be caused by different combination of drugs, control intervention, and patient populations.

Injection of methylene blue into the disk is widely accepted as a safe and effective method for the treatment of discogenic low back pain. ${ }^{17,19}$ Several potential limitations may exist in this meta-analysis. First, our analysis is based on only three RCTs and two of them have a relatively small sample size $(n<100)$. There is significant heterogeneity, which may be caused by different combination of drugs, control intervention, and patient populations, all of which may have an influence on the pooling results. Finally, some unpublished and missing data may lead to some bias.

\section{Conclusion}

Intradiskal methylene blue injection has beneficial effects on pain alleviation and functional improvement in patients with discogenic low back pain.

\section{Conflict of Interest \\ None declared.}

\section{References}

1 Luo L, Zhang C, Zhou Q et al. Effectiveness of transpedicular dynamic stabilization in treating discogenic low back pain. World Neurosurg 2018;111:e192-e198

2 Schwarzer AC, Aprill CN, Derby R, Fortin J, Kine G, Bogduk N. The prevalence and clinical features of internal disc disruption in patients with chronic low back pain. Spine 1995;20(17):1878-1883

3 Zhou Y, Abdi S. Diagnosis and minimally invasive treatment of lumbar discogenic pain: a review of the literature. Clin J Pain 2006;22(05):468-481

4 Simon J, McAuliffe M, Shamim F, Vuong N, Tahaei A. Discogenic low back pain. Phys Med Rehabil Clin N Am 2014;25(02):305-317

5 Bogduk N, Aprill C, Derby R. Lumbar discogenic pain: state-of-theart review. Pain Med 2013;14(06):813-836

6 Buirski G, Silberstein M. The symptomatic lumbar disc in patients with low-back pain. Magnetic resonance imaging appearances in both a symptomatic and control population. Spine 1993;18(13):1808-1811

7 Duan B, Cheng L, Ma Q. Spinal circuits transmitting mechanical pain and itch. Neurosci Bull 2018;34(01):186-193

8 Peng B, Wu W, Hou S, Li P, Zhang C, Yang Y. The pathogenesis of discogenic low back pain. J Bone Joint Surg Br 2005;87(01):62-67

9 Bertagnoli R, Yue JJ, Shah RV, et al. The treatment of disabling multilevel lumbar discogenic low back pain with total disc arthroplasty utilizing the ProDisc prosthesis: a prospective study with 2-year minimum follow-up. Spine 2005;30(19):2192-2199

10 Wainwright M, Crossley KB. Methylene blue: a therapeutic dye for all seasons? J Chemother 2002;14(05):431-443

11 Zhang L, Liu Y, Huang Z, et al. Toxicity effects of methylene blue on rat intervertebral disc annulus fibrosus cells. Pain Physician 2019; 22(02):155-164

12 Tan KY, Seow-Choen F. Methylene blue injection reduces pain after lateral anal sphincterotomy. Tech Coloproctol 2007;11(01):68-69
13 Vaccaro A, Patten SA, Ciura S, et al. Methylene blue protects against TDP-43 and FUS neuronal toxicity in C. elegans and D. rerio. PLoS One 2012;7(07):e42117

14 Volke V, Wegener G, Vasar E, Rosenberg R. Methylene blue inhibits hippocampal nitric oxide synthase activity in vivo. Brain Res 1999;826(02):303-305

15 Aneese AM, Ghaith G, Cannon ME, Manuballa V, Cappell MS. EUSguided methylene blue injection to facilitate endoscopic cannulation of an obscured pancreatic duct orifice after ampullectomy. Am J Gastroenterol 2018;113(05):782-783

16 Cohen SP, Williams KA, Kurihara C, et al. Multicenter, randomized, comparative cost-effectiveness study comparing 0,1 , and 2 diagnostic medial branch (facet joint nerve) block treatment paradigms before lumbar facet radiofrequency denervation. Anesthesiology 2010;113(02):395-405

17 Kallewaard JW, Wintraecken VM, Geurts JW, et al. A multicenter randomized controlled trial on the efficacy of intradiscal methylene blue injection for chronic discogenic low back pain: the IMBI study. Pain 2019;160(04):945-953

18 Zhang L. Effect of methylene blue injection on lumbar function and pain in patients with discogenic low back pain. J Nat Med 2018;3:312-313

19 Peng B, Pang X, Wu Y, Zhao C, Song X. A randomized placebocontrolled trial of intradiscal methylene blue injection for the treatment of chronic discogenic low back pain. Pain 2010;149 (01):124-129

20 Moher D, Liberati A, Tetzlaff J, Altman DGPRISMA Group. Preferred reporting items for systematic reviews and meta-analyses: the PRISMA statement. J Clin Epidemiol 2009;62(10):1006-1012

21 Jadad AR, Moore RA, Carroll D, et al. Assessing the quality of reports of randomized clinical trials: is blinding necessary? Control Clin Trials 1996;17(01):1-12

22 Zhao J, Huang W, Zhang S, et al. Efficacy of glutathione for patients with cystic fibrosis: a meta-analysis of randomized-controlled studies. Am J Rhinol Allergy 2020;34(01):115-121

23 Kjaergard LL, Villumsen J, Gluud C. Reported methodologic quality and discrepancies between large and small randomized trials in meta-analyses. Ann Intern Med 2001;135(11):982-989

24 Higgins JP, Thompson SG. Quantifying heterogeneity in a metaanalysis. Stat Med 2002;21(11):1539-1558

25 Delport A, Harvey BH, Petzer A, Petzer JP. Methylene blue analogues with marginal monoamine oxidase inhibition retain antidepressant-like activity. ACS Chem Neurosci 2018;9(12):2917-2928

26 Eide PK, Hole K. The role of 5-hydroxytryptamine (5-HT) receptor subtypes and plasticity in the 5 -HT systems in the regulation of nociceptive sensitivity. Cephalalgia 1993;13(02):75-85

27 Yaksh TL, Wilson PR. Spinal serotonin terminal system mediates antinociception. J Pharmacol Exp Ther 1979;208(03):446-453

28 Mentes BB, Akin M, Leventoglu S, Gultekin FA, Oguz M. Intradermal methylene blue injection for the treatment of intractable idiopathic pruritus ani: results of 30 cases. Tech Coloproctol 2004;8(01):11-14

29 Farrokhi MR, Lotfi M, Masoudi MS, Gholami M. Effects of methylene blue on postoperative low-back pain and functional outcomes after lumbar open discectomy: a triple-blind, randomized placebo-controlled trial. J Neurosurg Spine 2016;24(01):7-15

30 Peng B, Zhang Y, Hou S, Wu W, Fu X. Intradiscal methylene blue injection for the treatment of chronic discogenic low back pain. Eur Spine J 2007;16(01):33-38

31 Kallewaard JW, Geurts JW, Kessels A, Willems P, van Santbrink H, van Kleef M. Efficacy, safety, and predictors of intradiscal methylene blue injection for discogenic low back pain: results of a multicenter prospective clinical series. Pain Pract 2016;16(04): 405-412

32 Levi DS, Horn S, Walko E. Intradiskal methylene blue treatment for diskogenic low back pain. PM R 2014;6(11):1030-1037 